\title{
Education Levels among Parents and Misconceptions on HIV and AIDS
}

\author{
Methusela Mishael Masanja
}

Local Government Training Institute, Dodoma, Tanzania

\begin{abstract}
This study investigated the association between Parents' education levels and beliefs towards HIV/AIDS and People Living with HIV and AIDS (PLWHA). Data was collected using a set of questionnaire. Five points Likert was used to measure parents' attitudes and beliefs towards HIV/AIDS and PLWHA. Findings from this study show that age, sex, religion, and occupations had no significant influence on beliefs but differences in education level exerted difference in beliefs of respondents towards HIV and AIDS and PLWHA $(p=0.010)$. Misconceptions and negative beliefs towards HIV/AIDS and PLWHA among parents with no formal education should be fought.
\end{abstract}

Keywords: Education level, HIV and AIDS, Beliefs

\section{HIV AND AIDS KNOWLEDGE}

According to UN (2005), the level of awareness is higher in over half of African, Asian, and Latin American countries whereby at least $90 \%$ of the population has heard of HIV/AIDS. However, in most countries awareness is higher among men than in women. Urban residents are also known to be much more aware than the rural population, and more education is associated with greater awareness and better knowledge (Sudha, 2005; Shrotri, 2003). It is obvious that awareness and appropriate knowledge may play an important role in preventing further spread of HIV/AIDS (Li et al., 2004).

\section{Attitudes ANd Beliefs towards HIV/AIDS AND PLWHA}

A number of misconceptions surround HIV/AIDS and PLWHA. Less educated people tend to be less knowledgeable, more fearful towards AIDS, and more likely to have negative attitudes about PLWHA (Lau and Tsui, 2005; Tavoosi et al., 2004). Thus, negative attitudes commonly arise from ignorance rising from people who do not know how the virus is transmitted. In communities with many people dying at a young age, lack of information about the virus can cause fear leading people to come up with their own explanations and methods of eliminating the threat (Lass, 2007). In many societies HIV and AIDS are believed to bring shame upon the family or community (Fredriksson, and Kanabus, 2003).

\section{Education, Beliefs and HIV/AIDS}

Many Western-based AIDS prevention education and programmes have failed dismally in Africa, and they may only succeed if traditional African beliefs and customs are taken into account (Van Dyk, 2001). According to Eisenberg et al. (2004), medically inaccurate information appears to be tied to political rhetoric, as evidenced by the significantly higher proportion of very conservative parents who hold very negative and medically inaccurate views about condoms and oral contraceptives. Disentangling this information from political messages may be an important step toward educating parents across the political spectrum. Literacy plays a significant role in the understanding the various modes of transmission of HIV/AIDS (Manjrekar et al., 2014). Education has been suggested as a 'social vaccine' to prevent the spread of HIV/AIDS (Jukes et al., 2008). HIV interventions need to move beyond targeting specific populations based upon race/ethnicity, gender, sexual, drug and/or risk behaviors and incorporate cultural beliefs and experiences relevant to an individual's risk (Wyatt et al., 2012). Belief is an important aspect in HIV and AIDS prevention if an effective and positive change is desired (Odu and Akanle, 2008).

\section{Methodology}

Sixty randomly selected parents in Maswa District in Tanzania were involved in this study. A set of questionnaire including five points Likert scale was used for data collection. Attitudes and beliefs towards HIV/AIDS and PLWHA were determined. Chi-square statistic was used to test for differences in attitudes and beliefs among parents with different levels of education.

\section{RESULTS}

Attitudes of parents towards HIV/AIDS and PLWHA Five points likert scale including strongly disagree, disagree, undecided, agree and strongly agree was used to measure parents' attitudes towards HIV/AIDS and PLWHA. Table 1 summarizes the results whereby $50 \%$ of parents had positive attitudes towards HIV/AIDS and PLWHA, 31.7\% had negative attitudes, and $18.3 \%$ were undecided. 
Table 1: Parent attitudes towards HIV / AIDS and PLWHA

\begin{tabular}{ll}
\hline Attitudes & Percent \\
\hline Negative attitudes $(n=19)$ & 31.7 \\
Undecided $(n=11)$ & 18.3 \\
Positive attitudes $(n=30)$ & 50.0 \\
\hline
\end{tabular}

\section{Factors Influencing the PARENTS' AtTItUdes TOWARDS HIV/AIDS AND PLWHA}

Six factors (variables) were tested using chi-square statistical test. Results are as summarized in Table 2. Sex, ethnicity and occupations showed significant influence on attitudes towards HIV/AIDS and PLWHA. However, there was no significance difference among parents of different age, education level and religion on attitudes towards HIV / AIDS and PLWHA.

Findings of this study show age categories among parents had no influence on parents' attitudes towards HIV / AIDS and PLWHA (Table 2). Lack of age influence on attitudes may be due the fact that in the rural areas people have same/common sources of information this may have lead them to respond alike. Education levels among parents were also tested (Table 2). This study found no significant difference in attitudes among parents of different education levels $(p=0.224)$. However, Ayranci (2005) found that there were significant differences between individuals with different levels of education. Those with higher education were significantly more positive in their attitudes compared to less educated respondents. Tayoosi et al. (2004) too found that attitude was significantly correlated with knowledge in which respondents with less knowledge scores had more negative attitude towards HIV positive patients. This study also revealed similarity in attitudes towards HIV / AIDS and PLWHA among different religious groups $(p=0.213)$. This is not surprising as mostly religious people all over the world of different beliefs has same stand on HIV / AIDS (Badahdah, 2005) as they argue that AIDS is God's punishment for immorality and promiscuity.

a) Sex: Most female parents (72\%) showed positive attitudes contrary to male parents in which only $34.3 \%$ had positive attitudes (Table 2). The difference is statistically significant $(\mathrm{p}=0.008)$. Similar findings were noted by Ayranci (2005) whereby women had positive attitudes towards HIV / AIDS or AIDS victims compared to men who had negative attitudes.

b) Ethnicity: Less than a half (42.2\%) of Sukuma had negative attitudes while other tribes had a higher proportion $(87.6 \%)$ with positive attitudes towards HIV / AIDS and PLWHA. The observed difference was statistically significant at $p=0.002$. This difference may be due to different cultural background and exposure among parents from other ethnic groups who may have come in those rural areas from various areas making them more tolerant towards HIV / AIDS and PLWHA.

c) Occupation: Majority of peasants, Government employees and businesspersons had positive attitudes while about two-thirds of religious leaders $(66.7 \%)$ had negative attitudes (Table 2). The differences were statistically significant $(\mathrm{p}=0.022)$. These results are not surprising as religious leaders believe that AIDS is a punishment from God as it is contracted through sex relationships. It is then believed that if someone is suffering from HIV/AIDS he/she must have broken societal norms or committed adultery. The disease is considered as a deserving punishment for immoral behavior (Sudha et al., 2005). It is known that this attitude puts PLWHA into unnecessary hostile and embarrassing situation facing discrimination and neglect (URT, 2001).

Table 2: Characterization of Parents attitudes towards HIV / AIDS and PLWHA

\begin{tabular}{|c|c|c|c|c|c|c|}
\hline Variables/categories & \multicolumn{4}{|c|}{ Attitudes towards HIV/PLWHA(\%) } & \multicolumn{2}{|l|}{ Level of Significance } \\
\hline & 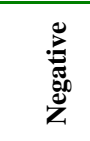 & 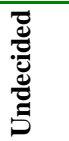 & 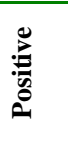 & $\stackrel{\bar{\pi}}{6}$ & & \\
\hline Below 35 years $(n=26)$ & 19.2 & 23.1 & 56.7 & 100 & & \\
\hline Between 35 and 45 years $(n=20)$ & 50.0 & 15.0 & 35.0 & 100 & $\left(X^{2}=5.351\right), p=0.253$ & \\
\hline Above 45 years $(n=14)$ & 28.6 & 14.3 & 57.1 & 100 & & \\
\hline \multirow{3}{*}{$\begin{array}{ll}\text { Sex: } & \text { Males }(\mathrm{n}=35) \\
& \text { Females }(\mathrm{n}=25) \\
\text { Education: } & \text { No formal education }(\mathrm{n}=2)\end{array}$} & 37.1 & 28.6 & 34.3 & 100 & $\left(X^{2}=9.747\right), p=0.008$ & ** \\
\hline & 24.0 & 4.0 & 72.0 & 100 & & \\
\hline & 100 & 0.0 & 0.0 & 100 & & \\
\hline Primary school education $(n=35)$ & 31.4 & 11.4 & 57.2 & 100 & $\left(\mathrm{X}^{2}=8.202\right), \mathrm{p}=0.224$ & \\
\hline Secondary school education $(n=13)$ & 30.8 & 30.8 & 38.4 & 100 & & \\
\hline Beyond sec. school educ. $(\mathrm{n}=10)$ & 20.0 & 30.0 & 50.0 & 100 & & \\
\hline Religion: Christian $(n=55)$ & 30.9 & 18.2 & 50.9 & 100 & & \\
\hline $\operatorname{Muslim}(n=3)$ & 0.0 & 33.3 & 66.7 & 100 & $\left(X^{2}=5.820\right), p=0.213$ & \\
\hline Traditional religion $(n=2)$ & 0.0 & 50.0 & 50.0 & 100 & & \\
\hline Ethnic group: Sukuma (n= 45) & 42.2 & 20.0 & 37.8 & 100 & $\left(X^{2}=11.984\right), p=0.002$ & $* *$ \\
\hline Others $(n=15)$ & 0.0 & 13.3 & 86.7 & 100 & & \\
\hline Occupations: Peasant $(\mathrm{n}=31)$ & 29.0 & 19.4 & 51.6 & 100 & & \\
\hline Govt employee $(\mathrm{n}=17)$ & 23.5 & 17.6 & 58.8 & 100 & $\left(\mathrm{X}^{2}=8.222\right), \mathrm{p}=0.022$ & $*$ \\
\hline Business person $(n=6)$ & 33.3 & 0.0 & 66.7 & 100 & & \\
\hline Religious leader $(n=6)$ & 66.7 & 33.3 & 0.0 & 100 & & \\
\hline
\end{tabular}

$*=$ significance difference at $\mathrm{p} \leq 0.05$

$\mathrm{X}^{2}=$ Chi-square

$* *=$ significance difference at $p \leq 0.01$ 


\section{BELIEFS OF PARENTS ON HIV/AIDS AND PLWHA}

Age, sex, education level, religion, ethnicity, and occupations of parents were considered when testing for beliefs of parents on HIV/AIDS and PLWHA (Table 3). Only differences in education level exerted difference in beliefs of respondents $(p=0.010)$.

With an exception of those with no formal education, parents with other different levels of education had positive beliefs towards HIV / AIDS and PLWHA (Table 3). The difference is statistically significant $(\mathrm{p}=0.010)$. This can be attributed to the fact that those who were highly educated were more aware of HIV/AIDS infection and means of transmission thus they had positive beliefs to HIV/AIDS and PLWHA reflecting their educational background (Ayranci, 2005; Sudha et al., 2005).

Table 3: Test results of Chi-square on parents' beliefs towards HIV/ AIDS and PLWHA

\begin{tabular}{|c|c|c|c|c|c|}
\hline & Variables & Belie & & & \\
\hline & & Negative & Positive & Level of signif & icance \\
\hline Age & Below 35 years $(n=26)$ & 34.6 & 65.4 & & \\
\hline & Between 35 and 45 years $(n=20)$ & 20.0 & 80.0 & $\mathrm{p}=0.552$ & \\
\hline & Above 45 years $(n=14)$ & 28.6 & 71.4 & & \\
\hline Sex & Males $(\mathrm{n}=35)$ & 28.6 & 71.4 & $\mathrm{p}=0.961$ & \\
\hline & Females $(n=25)$ & 28.0 & 72.0 & & \\
\hline Education & No formal education $(n=2)$ & 50.0 & 50.0 & & \\
\hline & Primary school education $(n=35)$ & 17.1 & 82.9 & $\mathrm{p}=0.010$ & $* *$ \\
\hline & Secondary school education $(n=13)$ & 23.1 & 76.9 & & \\
\hline & Beyond sec. school educ. $(\mathrm{n}=10)$ & 30.0 & 70.0 & & \\
\hline Religion & Christian $(n=55)$ & 27.3 & 72.7 & & \\
\hline & Muslim $(n=3)$ & 33.3 & 66.7 & $\mathrm{p}=0.617$ & \\
\hline & Traditional religion $(n=2)$ & 50.0 & 50.0 & & \\
\hline Ethnic group & Sukuma $(n=45)$ & 20.0 & 80.0 & $\mathrm{p}=0.053$ & \\
\hline & Others $(n=15)$ & 46.7 & 53.3 & & \\
\hline Occupation & Peasant $(\mathrm{n}=31)$ & 12.9 & 87.1 & & \\
\hline & Govt employee $(\mathrm{n}=17)$ & 41.2 & 58.8 & $\mathrm{p}=0.078$ & \\
\hline & Business person $(n=6)$ & 33.3 & 66.7 & & \\
\hline & Religious leader $(n=6)$ & 16.7 & 83.3 & & \\
\hline
\end{tabular}

** $=$ Significance difference at $\mathrm{p} \leq 0.010$

\section{Conclusions}

From the findings of this study it is concluded that: There are favorable attitudes towards HIV and AIDS and PLWHA in the study area regardless of differences in age, sex, education levels, occupations, religions and ethnic groups among parents.

Parents' age, sex, religion, ethnicity and occupations have no influence on their beliefs towards HIV/AIDS and PLWHA. However, education levels have influence on their beliefs whereby parents with no formal education have negative beliefs towards HIV/AIDS and PLWHA.

\section{RECOMMENDATIONS}

Special HIV / AIDS education campaign should be carried to fight misconceptions, and change unfavorable beliefs towards HIV/AIDS and PLWHA among parents with no formal education.

\section{REFERENCES}

Ayranci, A (2005); AIDS knowledge and attitudes in a Turkish population: an epidemiological study. BMC Public Health 5:95 [http://www.biomedcentral.com/1471-2458/5/95] Site visited on $17 / 6 / 2014$

Badahdah, A (2005); Saudi attitudes towards people living with HIV/AIDS. International Journal of STD \& AIDS 16 (12): 837- 838

Eisenberg, M. E., Bearinger, L. H., Sieving, R. E., Swain, C., and Resnick, M. D. (2004). Parents' Beliefs About Condoms and
Oral Contraceptives: Are They Medically Accurate? Perspectives on Sexual and Reproductive Health 36(2):50 - 57.

Fredriksson, J and Kanabus, A. (2003). HIV AND AIDS Stigma and Discrimination Attitudes Towards HIV and AIDS;Stigma and discrimination is the theme for World AIDS Day 2003 [http://www.e-alliance. ch/media/media-4293.doc] Accessed on $10 / 7 / 2014$

Hadhrami SA, Saaban AB, Ibrahim AB, Shahzad M and Ahmad I. 2014. Linear Active Control Algorithm to Synchronize a Nonlinear HIV/AIDS Dynamical System Asian Journal of Applied Science and Engineering, 3, 96-113.

Jukes, M., Simmons, S., Bundy, D. (2008). Education and vulnerability: the role of schools in protecting young women and girls from HIV in southern Africa. AIDS 22: 41-56.

Lass, G. (2007). Older people, HIV and AIDS.[http://www.avert.org/older-people. htm] Accessed $20 / 7 / 2014$

Lau, J. T. F. and Tsui, H. Y. (2005); Discriminatory attitudes towards people living with HIV/AIDS and associated factors: a population based study in the Chinese general population. Sex Transm Infect 81: $113-119$.

Li, X., Lin, C., Gao, Z., Stanton, B., Fang, X., Yin, Q., and Wu, Y. (2004); HIV / AIDS knowledge and the implications for health promotion programs among Chinese college students: geographic, gender and age differences. Health Promotion International 19(3): 345 - 356.

Manjrekar, S., Sherkhane, M., Chowti, J. (2014). Perceptions and outlook towards HIV/AIDS among reproductive age group of urban slum population. International Journal of Medical Science and Public Health 3: 808 - 812. 
Masanja MM and Msuya JM. 2014. Social Changes Imposed by HIV and AIDS in Rural Areas: An Empirical Evidence of Sex Education in Maswa District, Tanzania Asian Journal of Applied Science and Engineering, 3, 49-60.

Odu, B. K. and F. F. Akanle, (2008). Belief about HIV/AIDS: An obstacle to change in attitude to sex among undergraduate youths in South West Nigeria. Research in Education 79: 13.

Shrotri, A., Shankar, A. A., Sutar, S., Joshi, A., Suryawanshi, N., Pisal, H., Bharucha, K. E., Phadke, M. A., Bollinger, R. C., Sastry, J. (2003); Awareness of HIV/AIDS and household environment of pregnant women in Pune, India. International Journal of STD \& AIDS 14: 835 - 839.

Sudha, R. T., Vijay, D. T., Lakshmi V. (2005); Awareness, attitudes, and beliefs of the general public towards HIV/Aids in Hyderabad, a capital city from South India. Indian Journal of Medical Sciences 59(7): 307 - 316.
Tavoosi, A., Zaferani, A., Enzevaei, A., Tajik, P., and Ahmadinezhad, Z. (2004) Knowledge and attitude towards HIV/AIDS among Iranian students. BMC Public Health 4: 17.

UN (2005). Millennium Development Goals. [http:/ /www.un.org/ millenniumgoals/\#] Accessed 4 May 2014

URT, (2001); The Prime Minister's Office; National Policy on HIV/AIDS. [http://www.Policyproject.com/pubs/other/Tanzania_Na tional_Policy_on_HIV-AIDS.pdf] Accessed on 10/07/2014

Van Dyk, A. C. (2001). Traditional Africanï i ${ }^{1 / 2}$ beliefs and customs: Implications for AIDS education and prevention in Africa. South African Journal of Psychology 31(2): 60.

Wyatt, G. E., Williams, J. K., Malebranche, D. (2012). Are Cultural Values and Beliefs Included in U.S. Based HIV Interventions? Preventive Medicine 55(5):362-370.

Zahan N. 2013. HIV/AIDS Risk among the Children of Bangladesh: An overview $A B C$ Journal of Advanced Research, 2, 30-43.

\section{How to Cite}

Masanja MM. 2014. Education Levels among Parents and Misconceptions on HIV and AIDS Asian Business Review, 4, 105-108. 